\title{
Nutritional Quality of Newly Developed Kharif Sorghum Genotypes
}

\author{
U.D. Chavan", S.T. Kajjdoni, M.S. Shinde, U.S. Dalvi, S.V. Nirmal, \\ V.R. Patil, V.R. Awari, G.H. Pawar and A.S. Jadhav
}

All India Coordinated Sorghum Improvement Project, Mahatma Phule Krishi Vidyapeeth, Rahuri, Dist: Ahmednagar (MS), India

*Corresponding author

\begin{tabular}{|c|c|}
\hline & A B S T R A C T \\
\hline Keywords & For higher yield, resistance to pest and disease and having good nutritional \\
\hline $\begin{array}{l}\text { Sorghum } \\
\text { genotypes, } \\
\text { Nutritional quality, } \\
\text { roti quality, Dough } \\
\text { quality. }\end{array}$ & $\begin{array}{l}\text { centers were grown at AICRP on sorghum During Kharif-2016, total } 30 \\
\text { sorghum genotypes from advanced varietal trials (AVT) and advanced } \\
\text { hybrid trials (AHT) were evaluated for flour, dough, roti and nutritional } \\
\text { quality parameters. On the basis of physical and nutritional quality }\end{array}$ \\
\hline Article Info & parameters among the new sorghum genotypes from AVT; SPV 2308, SPV \\
\hline $\begin{array}{l}\text { Accepted: } \\
\text { 04 October } 2017 \\
\text { Available Online: } \\
10 \text { December } 2017\end{array}$ & $\begin{array}{l}\text { SPH CSH } 14 \text { were found promising for flour, dough, roti and nutritional } \\
\text { quality parameters. These genotypes can be used in the breeding } \\
\text { programme to get good quality grains. }\end{array}$ \\
\hline
\end{tabular}

\section{Introduction}

In India sorghum is traditionally consumed in the form of unleavened pan cake/ Roti/Bhakari. Because of sorghum is a staple food in many parts of the country. Though sorghum grains are nutritious, the consumption of this cereal is decreasing due to non-availability of easy cooking raw materials from the sorghum. The other major reasons are; dying traditional food habits, requirement of special skill for preparing sorghum rotis. For many years sorghum eating population particularly in rabi growing areas, the roti made from Maldandi (M 35-1) is preferred for taste and softness, over other genotypes. But now days some new genotypes of rabi sorghum are developed which gives better nutritional as well as organoleptic quality of the roti than the M 351. The most common products are leavened and unleavened breads, porridges, boiled grains and steam cooked products such as couscous. Sorghum flour also makes an excellent fry coating for fish, chicken and beef. Sorghum is also used in the preparation of several snacks and for popping, chewing, and malting (Rao and Murty, 1981). Sorghum roti is very popular in villages and small towns as an accompaniment to gravy meat and vegetable curries and is one of the traditional recipes of India. It is round, flat, 
unleavened bread often used in the cuisine of western and central India, especially in the states of Gujarat, Sorghum roti is known by various names in the different languages of India: chapati (Hindi), bhakri (Marathi), rotla (Gujarati), rotte (Telugu), etc. (Subramanian and Jambunathan, 1981; Chavan et al., 2016a, b). Because sorghum flour is gluten-free flour, it is very tough to spread the dough without breaking the shape and one really needs hands-on experience and many failed attempts to get the skill. No leavening agents, oil/ghee are added. Just fresh sorghum flour, warm water and touch of fire - pure grain power in its glory. Arabinoxylans have been isolated from different cereals and responsible to play important role in maintaining water balance and rheological properties of dough (Michniewicz et al., 1991; Vietor et al., 1992; Nandini et al., 2001).

There is a considerable variation in sorghum for levels of proteins, lysine, lipids, carbohydrates, fiber, calcium, phosphorus, iron, thiamine, and niacin (Chavan et al., 2009, 2010; Chavan et al., 2016c, d, e). Sorghum has chemical composition similar to or better than rice and wheat in some respects. The grains contain high fiber and non-starchy polysaccharides and starch with some unique characteristics. Protein quality and essential amino acid profile of sorghum is better than many of the cereals. Sorghum in general is rich source of B-complex vitamins. Developing new sorghum genotypes with high yield potential coupled with nutritionally superior quality grains is the prime objective of the breeding programme. This paper deals with the details of nutritional quality of newly developed grain sorghum genotypes by systematic breeding programme and compared with the local check. A study was done on the flour, dough, roti and nutritional quality of AVT-19 and AHT-11 trials of Kharif-2016, sorghum genotypes grown at Dharwad to identify superior genotypes.

\section{Materials and Methods}

\section{Material: Sorghum grains}

Newly developed sorghum grain samples from advanced varietal trials (AVT) and advanced hybrid trials (AHT) were obtained from all India Co-ordinated Sorghum Improvement Project, Dharwad, Karnataka, India during Kharif-2016 season from advanced varietal and hybrid trials.

\section{Methods: Cleaning sorghum grains}

The sorghum grains were cleaned to remove all extraneous material.

\section{Milling of sorghum grains}

Cleaned sorghum grains were subjected to milling in laboratory grinding mill. Whole sorghum flour was used for nutritional quality parameters testing and preparation of roti product.

\section{Physical parameters}

The physical parameters such as hectoliter weight $(\mathrm{kg} / \mathrm{hl})$, water absorption of flour $(\%)$, Kneading quality (Scale 1-3), Spreading quality (Scale 1-3), water required for dough (\%) were estimated by standard methods of AOAC, (1990).

\section{Nutritional quality of sorghum grain}

The sorghum grain flour was then analyzed for crude protein, total sugars, soluble protein, and free amino acids and phenolics contents using standard procedure of AOAC, (1990).

\section{Preparation of sorghum roti}

The flour was made from milling grains and fine flour was made in to dough with water. The $100 \mathrm{~g}$ sorghum flour was taken for 
preparation of roti. The dough was well kneaded, divided into small balls, flattened on a hard wooden or metal surface sprinkled with a small quantity of flour and was baked on both sides on a hot pan (Shobha et al., 2008). The prepared rotis were then kept in bamboo basket covered with cloth piece and stored at room temperature for studying the extension of shelf life.

\section{Sensory evaluation of sorghum roti}

The sensory evaluation for different quality parameters like colour and appearance, flavour, texture, taste and overall acceptability was carried out immediately after preparation of roties at room temperature by semi trained panel of 10 judges on a 9 point hedonic scale (Amerine et al., 1980). The storage study was carried out and weight loss was measured at every $4,8,12$ and $24 \mathrm{~h}$.

\section{Statistical analysis}

All results obtained in the present study were analysed using standard methods of Panse and Sukatme (1967).

\section{Results and Discussion}

Total nineteen AVT and eleven AHT advanced genotypes which included varieties and hybrids were compared with local check genotype. The results on flour, dough, roti and nutritional quality are presented in Tables 1 to 4 .

\section{Hectoliter weight}

The hectoliter weight gives the soundness of the grain as well as higher recovery of the flour. It is a unit weight of the grain in a specific volume. The hectoliter weight ranged from 78.40 to $81.41 \mathrm{~kg} / \mathrm{hl}$ for AVT and 78.48 to 82.36 for AHT trials respectively. The SPH 1779 genotype gave higher hectoliter weight than rest of the genotypes studied in AVT and AHT trials (Tables 1 and 3).

\section{Water absorption capacity}

The water absorption capacity is positively correlated to the roti quality. The higher the water absorption capacity the superior was the quality of the roti. The water absorption capacity of flour ranged from 71 to $93 \%$ for AVT and 73 to 86 for AHT trials. The genotype SPV 2358 gave higher water absorption percentage than other genotypes.

\section{Crude protein}

The crude protein content ranged from $9.18 \%$ (SPV 2357) to $11.69 \%$ (SPV 2301) in the advanced varietal genotypes studied with their checks. In AHT protein content ranged from $8.55 \%$ (SPH 1820) to $12.01 \%$ (SPH 1816) which is higher than the local check studied (Tables 1 and 3).

\section{Soluble protein}

The soluble protein content in the flour mostly responsible for the holding more water and developing smoothness to the roti. The soluble protein content in the flour ranged from $0.17 \%$ [SPV 2373] to $0.94 \%$ [SPV 2293) in AVT trials. In AHT soluble protein ranged from 0.41 (SPH 1779) to $0.90 \%$ (SPH 1813). All the genotypes were significantly different in their soluble content.

\section{Total soluble sugars}

In AVT trials the total soluble sugars ranged from $1.45 \%$ (CSV 17) to $2.45 \%$ (SPV 2363). In AHT total sugar content ranged from 1.54 (SPH 1817) to $2.10 \%$ (CSH 25). All the genotypes studied were significantly different. The higher sugar percentage in sorghum flour representing good amylolytic activity while preparation of roti. 
Table.1 Nutritional constituents responsible for roti quality prepared from different genotypes of Kharif -2016 (AVT) sorghum

\begin{tabular}{|c|c|c|c|c|c|c|c|c|c|c|}
\hline $\begin{array}{l}\text { Genotype/ } \\
\text { Entry code }\end{array}$ & $\begin{array}{l}\text { Colour } \\
\text { of the } \\
\text { grain }\end{array}$ & $\begin{array}{c}\text { Appearance/ } \\
\text { Shape of } \\
\text { the grain }\end{array}$ & $\begin{array}{l}\text { Hectoliter } \\
\text { weight } \\
(\mathrm{Kg} / \mathrm{hl})\end{array}$ & $\begin{array}{c}\text { Water } \\
\text { absorption } \\
(\mathrm{ml} / 100 \mathrm{~g})\end{array}$ & $\begin{array}{c}\text { Crude } \\
\text { Protein } \\
(\%)\end{array}$ & $\begin{array}{c}\text { Soluble } \\
\text { proteins } \\
(\%)\end{array}$ & $\begin{array}{c}\text { Total } \\
\text { sugars } \\
(\%)\end{array}$ & Starch $(\%)$ & $\begin{array}{c}\text { Free amino } \\
\text { acids } \\
(\mathrm{mg} / 100 \mathrm{~g})\end{array}$ & $\begin{array}{c}\text { Phenolics } \\
(\%)\end{array}$ \\
\hline SPV 2358 & DB & $\mathrm{RO}$ & 79.91 & 93 & 9.94 & 0.45 & 1.86 & 66.44 & 80.70 & 1.46 \\
\hline CSV 17 & DB & $\mathrm{RO}$ & 81.17 & 85 & 10.71 & 0.37 & 1.45 & 67.67 & 78.11 & 2.25 \\
\hline SPV2364 & DB & RO & 81.02 & 84 & 11.00 & 0.45 & 2.14 & 63.09 & 79.11 & 1.66 \\
\hline SPV 2370 & DB & RO & 80.62 & 86 & 11.17 & 0.42 & 1.78 & 58.04 & 63.71 & 1.93 \\
\hline SPV 2373 & DB & RO & 80.31 & 76 & 10.15 & 0.17 & 1.49 & 63.09 & 92.02 & 1.69 \\
\hline SPV 2357 & DB & RO & 80.08 & 77 & 9.18 & 0.83 & 1.89 & 65.65 & 75.17 & 1.56 \\
\hline SPV 2308 & $\mathrm{DB}$ & $\mathrm{RO}$ & 80.55 & 76 & 10.33 & 0.56 & 1.90 & 61.47 & 82.83 & 1.59 \\
\hline SPV 2301 & DB & RO & 81.09 & 74 & 11.69 & 0.49 & 2.17 & 59.51 & 76.25 & 2.43 \\
\hline SPV 2366 & $\mathrm{DB}$ & RO & 78.40 & 73 & 10.04 & 0.68 & 2.22 & 66.48 & 78.88 & 1.42 \\
\hline CSV 27 & $\mathrm{DB}$ & RO & 80.59 & 76 & 11.45 & 0.57 & 2.20 & 62.32 & 86.22 & 2.37 \\
\hline SPV 2293 & DB & RO & 78.52 & 78 & 10.57 & 0.94 & 2.19 & 70.71 & 73.25 & 2.04 \\
\hline SPV 2307 & DB & RO & 80.61 & 75 & 10.39 & 0.23 & 2.00 & 62.54 & 82.68 & 1.60 \\
\hline SPV 2372 & $\mathrm{DB}$ & RO & 78.95 & 72 & 10.98 & 0.66 & 1.88 & 64.66 & 91.45 & 1.84 \\
\hline SPV 2362 & $\mathrm{DB}$ & $\mathrm{RO}$ & 80.09 & 76 & 10.88 & 0.51 & 2.21 & 68.72 & 85.51 & 1.99 \\
\hline CSV 20 & $\mathrm{DB}$ & $\mathrm{RO}$ & 80.61 & 74 & 10.58 & 0.64 & 2.21 & 66.82 & 83.59 & 1.66 \\
\hline SPV 2363 & $\mathrm{DB}$ & $\mathrm{RO}$ & 81.33 & 77 & 11.44 & 0.20 & 2.45 & 60.87 & 95.28 & 1.71 \\
\hline SPV 2296 & DB & RO & 80.66 & 73 & 11.30 & 0.58 & 2.28 & 66.76 & 87.70 & 2.06 \\
\hline CSV 23 & DB & RO & 79.86 & 71 & 10.95 & 0.33 & 1.76 & 60.85 & 83.73 & 1.96 \\
\hline DSV 6 & $\mathrm{DB}$ & $\mathrm{RO}$ & 81.41 & 78 & 11.01 & 0.41 & 2.21 & 63.03 & 78.42 & 1.46 \\
\hline Range & - & - & $78.40-81.41$ & $71-93$ & $9.18-11.69$ & $0.17-0.94$ & $1.45-2.45$ & 58.04-70.71 & $63.71-95.28$ & $1.42-2.43$ \\
\hline Mean & - & - & 80.30 & 78 & 10.72 & 0.50 & 2.02 & 64.14 & 81.82 & 1.83 \\
\hline S.E. \pm & - & - & 0.85 & 5 & 0.60 & 0.19 & 0.26 & 3.24 & 7.15 & 0.29 \\
\hline C.D. at $5 \%$ & - & - & 2.56 & 16 & 1.81 & 0.59 & 0.79 & 9.75 & 21.47 & 0.90 \\
\hline
\end{tabular}

Replications: 3

Grain colour: Creamy $=\mathrm{C}$, Creamy White $=\mathrm{CW}$, Dull White $=\mathrm{DW}$, White $=\mathrm{W}$, Brown $=\mathrm{B}$, and Dull Black $=\mathrm{DB}$

Grain Shape: Round $=\mathrm{R}$, Oval $/$ Oblong $=\mathrm{O}$ and Wrinkle $=\mathrm{W}$. 
Table.2 Organoleptic quality of roti prepared from different genotypes of Kharif-2016 (AVT) sorghum

\begin{tabular}{|c|c|c|c|c|c|c|c|c|c|c|c|c|}
\hline \multirow[t]{2}{*}{ Genotype } & \multirow{2}{*}{$\begin{array}{l}\text { Water } \\
\text { required } \\
\text { for dough } \\
\quad(\mathrm{ml})\end{array}$} & \multirow[t]{2}{*}{$\begin{array}{l}\text { Kneading } \\
\text { quality }\end{array}$} & \multirow[t]{2}{*}{$\begin{array}{l}\text { Spreading } \\
\text { quality }\end{array}$} & \multicolumn{5}{|c|}{ Organoleptic quality parameters } & \multirow{2}{*}{$\begin{array}{c}\text { Rank } \\
\text { by } \\
\text { DMR } \\
\text { T }\end{array}$} & \multicolumn{3}{|c|}{$\begin{array}{l}\text { Loss in weight during storage } \\
\qquad(\%)\end{array}$} \\
\hline & & & & $\begin{array}{c}\text { Colour \& } \\
\text { appearance }\end{array}$ & Flavour & Texture & Taste & $\begin{array}{c}\text { Overall } \\
\text { acceptabilit } \\
\mathrm{y}\end{array}$ & & $4 \mathrm{hrs}$ & $8 \mathrm{hrs}$ & $24 \mathrm{hrs}$ \\
\hline SPV 2358 & 75 & 1 & 1 & 8.6 & 7.6 & 7.8 & 8.2 & 8.05 & 2 & 2.39 & 4.25 & 10.27 \\
\hline CSV 17 & 75 & 1 & 1 & 7.0 & 7.0 & 7.6 & 7.6 & 7.30 & 10 & 2.45 & 4.17 & 10.18 \\
\hline SPV2364 & 70 & 1 & 1 & 8.6 & 7.2 & 7.6 & 8.0 & 7.85 & 5 & 2.25 & 4.26 & 10.15 \\
\hline SPV 2370 & 70 & 1 & 1 & 8.0 & 7.4 & 8.2 & 7.8 & 7.85 & 5 & 2.36 & 4.12 & 10.28 \\
\hline SPV 2373 & 60 & 1 & 1 & 7.2 & 6.8 & 7.6 & 6.6 & 7.05 & 12 & 2.34 & 4.26 & 10.15 \\
\hline SPV 2357 & 65 & 1 & 1 & 7.6 & 7.8 & 7.4 & 7.2 & 7.50 & 7 & 2.25 & 4.15 & 10.25 \\
\hline SPV 2308 & 65 & 1 & 1 & 8.6 & 7.8 & 8.0 & 8.2 & 8.15 & 1 & 2.46 & 4.03 & 10.28 \\
\hline SPV 2301 & 60 & 1 & 1 & 7.4 & 6.8 & 7.4 & 7.2 & 7.20 & 11 & 2.23 & 4.25 & 10.15 \\
\hline SPV 2366 & 65 & 1 & 1 & 8.8 & 8.0 & 7.4 & 8.4 & 8.15 & 1 & 2.33 & 4.18 & 10.11 \\
\hline CSV 27 & 65 & 1 & 1 & 7.0 & 7.8 & 7.2 & 7.8 & 7.45 & 8 & 2.16 & 4.18 & 10.27 \\
\hline SPV 2293 & 65 & 1 & 1 & 7.8 & 8.0 & 7.4 & 7.0 & 7.55 & 6 & 2.24 & 4.22 & 10.35 \\
\hline SPV 2372 & 60 & 1 & 1 & 7.4 & 6.8 & 6.6 & 6.8 & 6.90 & 13 & 2.23 & 4.24 & 10.15 \\
\hline SPV 2362 & 60 & 1 & 1 & 8.0 & 8.0 & 8.4 & 7.4 & 7.95 & 4 & 2.26 & 4.15 & 10.25 \\
\hline CSV 20 & 60 & 1 & 1 & 7.6 & 7.2 & 7.6 & 7.4 & 7.45 & 8 & 2.12 & 4.12 & 9.89 \\
\hline SPV 2363 & 65 & 1 & 1 & 7.6 & 7.2 & 7.2 & 7.2 & 7.30 & 10 & 2.23 & 4.31 & 10.01 \\
\hline SPV 2296 & 60 & 1 & 1 & 7.6 & 7.4 & 7.2 & 7.2 & 7.35 & 9 & 2.31 & 4.21 & 10.11 \\
\hline CSV 23 & 60 & 1 & 1 & 8.2 & 7.2 & 7.6 & 7.2 & 7.55 & 6 & 2.21 & 4.11 & 10.21 \\
\hline DSV 6 & 65 & 1 & 1 & 8.4 & 7.8 & 8.0 & 7.8 & 8.00 & 3 & 2.33 & 4.21 & 10.23 \\
\hline Range & $60-75$ & - & - & $7.0-8.8$ & $6.8-8.0$ & $6.6-8.4$ & $6.6-8.4$ & $6.90-8.15$ & - & $\begin{array}{l}2.12- \\
2.46\end{array}$ & $\begin{array}{l}4.11- \\
4.32\end{array}$ & $\begin{array}{l}9.89- \\
10.35\end{array}$ \\
\hline Mean & 65 & - & - & 7.8 & 7.4 & 7.6 & 7.5 & 7.57 & - & 2.29 & 4.20 & 10.18 \\
\hline S.E. \pm & 4 & - & - & 0.54 & 0.41 & 0.39 & 0.48 & 0.36 & - & 0.08 & 0.07 & 0.10 \\
\hline C.D. at $5 \%$ & 14 & - & - & 1.64 & 1.25 & 1.19 & 1.45 & 1.10 & - & 0.27 & 0.21 & 0.31 \\
\hline
\end{tabular}

Replications: 5 minimum

Kneading quality of dough, score: Good $=1$, Fair $=2$, Poor $=3$. Spreading quality of roti, score: Easy spreading without crack $=1$, Slightly difficult to spread with minute cracks $=2$, Difficult to spread with cracks $=3$. DMRT $=$ Duncan multiple range test.

Sensory score: Like extremely (Excellent) - 9, Like very much (Very good) - 8, Like moderately - 7, Like slightly-6, Neither like nor dislike - 5, Dislikes lightly -

4, Dislike moderately - 3, Dislike very much - 2, Dislike extremely-1. 
Table.3 Nutritional constituents responsible for roti quality prepared from different genotypes of Kharif-2016 (AHT) sorghum

\begin{tabular}{|c|c|c|c|c|c|c|c|c|c|c|}
\hline $\begin{array}{l}\text { Genotype/ } \\
\text { Entry code }\end{array}$ & $\begin{array}{l}\text { Colour } \\
\text { of the } \\
\text { grain }\end{array}$ & $\begin{array}{l}\text { Appearance/ } \\
\text { Shape of the } \\
\text { grain }\end{array}$ & $\begin{array}{l}\text { Hectoliter } \\
\text { weight } \\
(\mathrm{Kg} / \mathrm{hl})\end{array}$ & $\begin{array}{c}\text { Water } \\
\text { absorption } \\
(\mathrm{ml} / 100 \mathrm{~g})\end{array}$ & $\begin{array}{c}\text { Crude } \\
\text { Protein } \\
(\%)\end{array}$ & $\begin{array}{c}\text { Soluble } \\
\text { proteins } \\
(\%)\end{array}$ & $\begin{array}{l}\text { Total } \\
\text { sugars } \\
(\%)\end{array}$ & Starch (\%) & $\begin{array}{l}\text { Free amino } \\
\text { acids } \\
(\mathrm{mg} / 100 \mathrm{~g})\end{array}$ & $\begin{array}{c}\text { Phenolics } \\
(\%)\end{array}$ \\
\hline SPH 1779 & DB & RO & 82.36 & 68 & 9.43 & 0.41 & 1.76 & 68.07 & 82.61 & 1.25 \\
\hline CSH 30 & DB & RO & 81.62 & 76 & 9.82 & 0.55 & 1.70 & 63.72 & 65.47 & 1.29 \\
\hline SPH 1778 & DB & RO & 80.45 & 78 & 10.23 & 0.56 & 1.87 & 65.12 & 74.79 & 1.60 \\
\hline SPH 1816 & DB & RO & 80.81 & 73 & 12.01 & 0.52 & 2.10 & 60.82 & 76.24 & 2.69 \\
\hline SPH 1820 & DB & RO & 79.36 & 76 & 8.55 & 0.80 & 1.79 & 70.40 & 72.70 & 1.67 \\
\hline CSH 16 & DB & RO & 81.03 & 74 & 10.54 & 0.67 & 1.69 & 66.41 & 76.40 & 2.26 \\
\hline SPH 1789 & DB & RO & 81.38 & 76 & 10.25 & 0.51 & 2.07 & 62.63 & 89.56 & 1.35 \\
\hline SPH 1817 & DB & RO & 80.98 & 78 & 10.36 & 0.77 & 1.54 & 66.08 & 75.45 & 1.87 \\
\hline SPH 1813 & DB & RO & 81.88 & 86 & 9.58 & 0.90 & 2.03 & 64.65 & 76.95 & 1.54 \\
\hline CSH 25 & DB & RO & 80.97 & 76 & 10.84 & 0.69 & 2.10 & 67.63 & 76.89 & 2.24 \\
\hline CSH 14 & DB & RO & 78.48 & 78 & 9.65 & 0.66 & 1.68 & 63.44 & 66.44 & 1.71 \\
\hline Range & - & - & $\begin{array}{l}78.48- \\
82.36\end{array}$ & $73-86$ & $8.55-12.01$ & $0.41-0.90$ & $1.54-2.10$ & $60.82-70.40$ & $65.47-89.56$ & $1.25-2.69$ \\
\hline Mean & - & - & 80.85 & 76 & 10.11 & 0.64 & 1.85 & 65.36 & 75.77 & 1.77 \\
\hline S.E. \pm & - & - & 1.05 & 4 & 0.84 & 0.13 & 0.18 & 2.60 & 6.35 & 0.43 \\
\hline C.D. at $5 \%$ & - & - & 3.17 & 12 & 2.54 & 0.42 & 0.57 & 7.81 & 19.06 & 1.31 \\
\hline
\end{tabular}

Replications: 3

Grain colour: Creamy $=\mathrm{C}$, Creamy White $=\mathrm{CW}$, Dull White $=\mathrm{DW}$, White $=\mathrm{W}$, Brown $=\mathrm{B}$, and Dull Black $=\mathrm{DB}$.

Grain Shape: Round = R, Oval/Oblong $=\mathrm{O}$ and Wrinkle $=\mathrm{W}$. 
Table.4 Organoleptic quality of roti prepared from different genotypes of Kharif-2016 (AHT) sorghum

\begin{tabular}{|c|c|c|c|c|c|c|c|c|c|c|c|c|}
\hline \multirow[t]{2}{*}{ Genotype } & \multirow{2}{*}{$\begin{array}{l}\text { Water } \\
\text { required } \\
\text { for dough } \\
\quad(\mathrm{ml})\end{array}$} & \multirow{2}{*}{$\begin{array}{l}\text { Kneading } \\
\text { quality }\end{array}$} & \multirow{2}{*}{$\begin{array}{c}\text { Spreading } \\
\text { quality }\end{array}$} & \multicolumn{5}{|c|}{ Organoleptic quality parameters } & \multirow{2}{*}{$\begin{array}{l}\text { Rank } \\
\text { by } \\
\text { DM } \\
\text { RT }\end{array}$} & \multicolumn{3}{|c|}{ Loss in weight during storage $(\%)$} \\
\hline & & & & $\begin{array}{c}\text { Colour \& } \\
\text { appearance }\end{array}$ & Flavour & Texture & Taste & $\begin{array}{l}\text { Overall } \\
\text { accept } \\
\text { ability }\end{array}$ & & $4 \mathrm{hrs}$ & $8 \mathrm{hrs}$ & $24 \mathrm{hrs}$ \\
\hline SPH 1779 & 60 & 1 & 1 & 8.6 & 8.0 & 8.2 & 8.0 & 8.20 & 1 & 2.14 & 4.10 & 10.38 \\
\hline CSH 30 & 70 & 1 & 1 & 7.8 & 7.2 & 7.8 & 7.6 & 7.60 & 4 & 2.20 & 4.13 & 10.28 \\
\hline SPH 1778 & 70 & 1 & 1 & 7.6 & 7.0 & 7.2 & 6.8 & 7.15 & 6 & 2.25 & 4.23 & 10.21 \\
\hline SPH 1816 & 65 & 1 & 1 & 7.2 & 7.2 & 6.8 & 7.2 & 7.10 & 7 & 2.24 & 4.13 & 10.15 \\
\hline SPH 1820 & 60 & 1 & 1 & 6.6 & 6.4 & 6.4 & 6.8 & 6.55 & 9 & 2.15 & 4.18 & 10.22 \\
\hline CSH 16 & 60 & 1 & 1 & 6.8 & 7.0 & 6.4 & 7.0 & 6.80 & 8 & 2.32 & 4.24 & 11.21 \\
\hline SPH 1789 & 60 & 1 & 1 & 8.2 & 7.4 & 8.2 & 7.8 & 7.90 & 2 & 2.15 & 4.13 & 11.25 \\
\hline SPH 1817 & 65 & 1 & 1 & 7.4 & 7.2 & 7.0 & 6.8 & 7.10 & 7 & 2.26 & 4.27 & 10.19 \\
\hline SPH 1813 & 80 & 1 & 1 & 6.0 & 6.8 & 6.6 & 6.4 & 6.45 & 10 & 2.25 & 4.12 & 10.26 \\
\hline CSH 25 & 65 & 1 & 1 & 7.8 & 7.2 & 7.4 & 7.8 & 7.55 & 5 & 2.15 & 4.23 & 10.11 \\
\hline CSH 14 & 60 & 1 & 1 & 7.6 & 7.8 & 7.6 & 7.6 & 7.65 & 3 & 2.24 & 4.13 & 10.25 \\
\hline Range & $60-80$ & - & - & $6.0-8.6$ & $6.4-8.0$ & $6.4-8.2$ & $\begin{array}{l}6.4- \\
8.0\end{array}$ & $6.45-8.20$ & - & $2.15-2.26$ & $\begin{array}{l}4.10- \\
4.27\end{array}$ & $10.11-11.25$ \\
\hline Mean & 65 & - & - & 7.4 & 7.2 & 7.2 & 7.3 & 7.28 & - & 2.21 & 4.17 & 10.41 \\
\hline S.E. \pm & 6 & - & - & 0.70 & 0.41 & 0.63 & 0.50 & 0.52 & - & 0.05 & 0.05 & 0.39 \\
\hline C.D. at $5 \%$ & 18 & - & - & 2.12 & 1.25 & 1.89 & 1.52 & 1.59 & - & 0.17 & 0.17 & 1.18 \\
\hline
\end{tabular}

Replications: 5 minimum

Kneading quality of dough, score: Good $=1$, Fair $=2$, Poor $=3$. Spreading quality of roti, score: Easy spreading without crack $=1$, Slightly difficult to spread with minute cracks $=2$, Difficult to spread with cracks $=3$. DMRT $=$ Duncan multiple range test.

Sensory score: Like extremely (Excellent) - 9, Like very much (Very good) - 8, Like moderately - 7, Like slightly-6, Neither like nor dislike - 5, Dislikes lightly - 4, Dislike moderately - 3, Dislike very much - 2, Dislike extremely-1. 
Total soluble sugars are mostly responsible for good taste of the roti (Tables 1 and 3).

\section{Starch}

The starch content of the advanced varietal genotypes ranged from 58.04\% (SPV 2370) to 70.71\% (SPV 2293). In AHT starch ranged from $60.82 \%$ (SPH 1816) to $70.40 \%$ (SPH 1820). Higher starch content gives good colour and amylolytic activity during roti preparation.

\section{Free amino acids}

The free amino acids in the studied genotypes of AVT trials ranged from $63.71 \mathrm{mg} / 100 \mathrm{~g}$ flour (SPV 2370) to $95.28 \mathrm{mg} / 100 \mathrm{~g}$ flour (SPV 2363). In AHT trials free amino acids ranged from $65.47 \mathrm{mg} / 100 \mathrm{~g}$ flour (CSH 30) to $89.56 \mathrm{mg} / 100 \mathrm{~g}$ flour (SPH 1789). The advanced sorghum genotypes were significantly different in the free amino acid content. This component mostly responsible for aroma development while roasting combines with moisture, soluble proteins and sugars.

\section{Phenolics}

The phenolics content in the studied genotypes of AVT trials ranged from $1.42 \%$ (SPV 2366) to $2.43 \%$ (SPV 2301). In AHT trials phenolics content ranged from $1.25 \%$ (SPH 1779) to $2.69 \%$ (SPH 1816). The phenolics mostly responsible for astringent taste to the product but nowadays it acts as antioxidants which prevent cancer development in human body. These nutritional quality parameters results are in agreement with Glover et al., (1986), Chavan et al., (1988) and Chavan et al., (2010).

\section{Roti quality}

All grain samples of AVT and AHT trials of kharif-2016 season grown at Dharwad center were used for the roti preparation and then used for organoleptic evaluation (colour and appearance, texture, flavour/aroma, taste and overall acceptability using 1 to 9 hedonic scale rating (Tables 2 and 4). On the basis of these parameters and overall acceptability Duncan Multiple Range Taste was used to give the numbering for ranking the genotypes. For smoothness of the roti storage study was also conducted and water loss was measured at 4,8 and $24 \mathrm{hrs}$. These results are in accordance with the previous research work done by Subramanian and Jambunathan (1982), Salunkhe et al., (1984) and Shobha et al., (2008).

During Kharif-2016 total 30 sorghum genotypes from AVT (19) and AHT (11) were evaluated for flour, dough, roti and nutritional quality parameters using above parameters (Tables 1 to 4). On the basis of these characters among the new sorghum genotypes from AVT; SPV 2308, SPV 2366, SPV 2358 and DSV 6 and from AHT; SPH 1779, SPH 1789 and $\mathrm{CSH} 14$ were found promising for flour, dough, roti and nutritional quality.

\section{References}

Amerine, M. A., Pangborn, R. M. and Rossler, E.B. (1980). Principles of sensory evaluation of food. Academic Press, New York.

AOAC, (1990). Official Methods of Analysis. $15^{\text {th }}$ Edn. Association of Official Analytical Chemists, Washington, DC, pp.113-127.

Chavan U. D., Jagtap Y. K., Shinde M. S and Patil J. V. (2016b). Preparation and nutritional quality of sorghum chakali. International Journal of Recent Scientific Research. 7 (1): 8404-8411.

Chavan, U. D., Jagtap, Y. K., Dalvi, U. S. and Patil, J. V. (2016a). Preparation and Nutritional Quality of Sorghum Shankarpali. Int. J. Pure App. Biosci. 4 (1): 100-108.

Chavan, U. D., Nirmal, S. V., Gadakh, S. R., Pawar, G. H. and Shinde, M. S. (2016d). 
Effect of location on nutritional quality of sorghum grain and roti. International Journal of Current Research, 8 (8): 3686536869.

Chavan, U. D., Nirmal, S. V., Shinde, M. S., Pawar, G. H. and Gadakh, S. R. (2016c). Nutritional quality of advanced sorghum genotypes. International Journal of Recent Scientific Research. 7 (8): 13148-13151.

Chavan, U. D., Patil, J. V. and Shinde M. S. (2009). Nutritional and roti quality of sorghum genotypes. Indonesian Journal of Agriculture Science 10: 80-87.

Chavan, U. D., Yewale, K. V. and Dayakar Rao, B. (2016e). Preparation of bread and cookies from sorghum flour. International Journal of Recent Scientific Research. 7 (5): 1114511153.

Chavan, U.D., Bhagwat, V.R., Ratnavati, C.V., Patil, J.V., Gawali, H.S and Shailaja, V. (2010). Jwariche Ruchakar Padartha. Sorghum Research Centre, Rajendranagar, Hyderabad (India).pp. 26

Chavan, U.D., Bhagwat, V.R., Ratnavati, C.V., Patil, J.V., Gawali, H.S and Shailaja, V. (2010). Jwariche Ruchakar Padartha. Sorghum Research Centre, Rajendranagar, Hyderabad (India). pp. 26

Chavan, U.D., Chavan, J.K. and Kadam, S.S. (1988). Effect of fermentation on soluble proteins and in-vitro protein digestibility of sorghum, green gram and sorghum + green gram blends. J. Food Sci. 53 : 1574-1575.

Glover, J., Walker, C., and Mattern, P. (1986). Functionality of sorghum flour components in a high ratio cake. Journal of Food Science. 51: 1280-1283, 1292.

Michniewicz, J., Biliaderis, C. G. and Bushuk, W. (1991). Effect of added pentosans on some physical and technological characteristics of dough and gluten. Cereal Chemistry 68: 252-258.

Nandini C. D. and Salimath, P. V. (2001). Structural features of arabinoxylans from sorghum having good roti-making quality. Food Chemistry 74: 417 - 422.

Panse, V. G. and Sukhatme, P. V. (1967). Statistical Methods for Agricultural Workers $2^{\text {nd }}$ Edn. I.C.A.R., New Delhi.

Rao Prasada, K. E. and Murty, D. S. (1981). Sorghum for Special Uses. Proceedings of the International Symposium on Sorghum Grain Quality: 129-134.

Salunkhe D. K., J. K. Chavan and S. J. Jadhav. (1984). Nutritional and processing quality of sorghum. Oxford and IBH Publishing Co, New Delhi Pp. 275.

Shobha, V., Kasturiba, B., Naik, R. K. and Yenagi, N. (2008). Nutritive Value and Quality Characteristics of Sorghum Genotypes. Karnataka Journal of Agriculture Science 20: 586-588

Subramanian, V. and Jambhunathan, R. (1982). Properties of sorghum grain and their relationship to roti quality. In: International Symposium on sorghum grain quality. ICRISAT, Patancheru, India. pp. 280-288.

Subramanian, V. and Jambunathan, R. (1981). Properties of Sorghum Grain and their Relationship to Roti Quality. Proceedings of the International Symposium on Sorghum Grain Quality: 286-288.

Vietor, R. J., Angelino, S. A. G. F. and Voragen, A. G. J. (1992). Structural features of arabinoxylans from barley and malt cell wall material. Journal of Cereal Science 15: 213-222.

\section{How to cite this article:}

Chavan, U.D., S.T. Kajjdoni, M.S. Shinde, U.S. Dalvi, S.V. Nirmal, V.R. Patil, V.R. Awari, G.H. Pawar and Jadhav, A.S. 2017. Nutritional Quality of Newly Developed Kharif Sorghum Genotypes. Int.J.Curr.Microbiol.App.Sci. 6(12): 1-9.

doi: https://doi.org/10.20546/ijcmas.2017.612.001 